\title{
ENZYMATIC DEACETYLATION OF N-ACETYLHISTAMINE IN ANIMAL TISSUES
}

\author{
Yasuo ENDO and Yasumi OGURA \\ Department of Pharmacology, Schoot of Dentistry, Tohoku University, Sendai, Japan
}

Accepted January 24, 1975

\begin{abstract}
N}$-Acetylhistamine-deacetylating activity was observed in all tissues tested of rats, mice and guinea-pigs. The liver, kidney, spleen and brain showed the high enzymatic activity. The major part of activity was localized in the cellular soluble fraction. In the brain, enzymatic activity was localized in a similar level in both the $100,000 \mathrm{~g}$ supernatant and $10,000 \mathrm{~g}$ sediment. The deacetylating activity was markedly increased by the addition of $\mathrm{Mn}^{++}$. $\mathrm{Na}^{+}, \mathrm{K}^{+}, \mathrm{Li}^{+}, \mathrm{Ca}^{++}$and $\mathrm{Mg}^{++}$had no effect. The $\mathrm{Mn}^{++}$concentration optimum for the activity was in a range $0.5-1 \mathrm{mM} . \mathrm{Co}^{++} \mathrm{en}-$ hancel the activity at a low concentration and inhibited it at a high concentration. $\mathrm{Cu}^{++}, \mathrm{Zn}^{++}, \mathrm{Hg}^{++}, \mathrm{Cd}^{++}$and p-chloromercuric benzoate (PCMB) inhibited the activity. The PCMB-inhibited activity was partially restored by the addition of glutathione-SH or cysteine. The optimum $\mathrm{pH}$ of the enzymatic reaction was 8.0 in the presence of $\mathrm{Mn}^{++}$. These properties were common among the enzymes in different tissues.
\end{abstract}

The in viro acetylation of histamine has been demonstrated in normal and enterectomized rats following histamine administration, and $\mathrm{N}$-acetylhistamine was found in the urine, liver, lung and spleen $(1,2,3)$. On the other hand, Werle and Palm (4) reported the finding of a small amount of $\mathrm{N}$-acetylhistamine in the nerve of normal cows. Tabor et al. (5) showed the in vitro acetylation of histamine in a partially purified pigeon liver preparation that acetylated p-nitroaniline, p-aminobenzoic acid and numerous other amines as well as that of histamine. Mammalian tissues also have been found to contain an enzyme catalyzing the $\mathrm{N}$-acetylation of a number of biogenic amines $(6,7)$. Weissbach et al. (6) reported that out of several amines such as serotonin, tryptamine, phenylethylamine, tyramine, octopamine and normetanephrine, the amine-acetylating enzyme in the liver showed the highest substrate specificity for histamine.

On the other hand, Sjaastad (8) described the possibility of in vivo deacetylation of $\mathrm{N}$-acetylhistamine in man, as an increase in the urinary excretion of histamine after s.c. injection of $\mathrm{N}$-acetylhistamine was observed.

The enzymatic deacetylation of $\mathrm{N}$-acetylhistamine and some properties of the enzyme in animal tissues are described herein.

\section{MATERIALS AND METHODS}

Materials: N-Acetylhistamine was synthesized by Merwe's method (9) from histamine. P-Cellulose (capacity: $1.18 \mathrm{meg} / \mathrm{g}$ ) was obtained from Brown Co., U.S.A. and o-phthalaldehyde was purchased from Nakarai Chemicals, Lłd., Tokyo, Japan. The following 
animals were used in the experiments: male rats (Wistar, 300-400 g), male guinea-pigs (Hartley, 800-900 g), female mice (ddl, 20-25 g).

Preparation of enzyme: The animals were decapitated and the tissues were stored in a deep freezer at $-10 \sim-18^{\circ} \mathrm{C}$. All tissues were used within three days. Each tissue was homogenized in 7 yolumes of ice-cold $0.14 \mathrm{M} \mathrm{NaCl}$. The homogenate was centrifuged at $13,000 \mathrm{~g}$ for $20 \mathrm{~min}$ and both supernatant and sediment suspended in $0.14 \mathrm{M} \mathrm{NaCl}$ were used for the assay of enzymatic activity.

Assay of deacetylating activity of $N$-acetylhistamine: Enzymatic activity was assayed by the estimation of histamine produced by the deacetylation of $\mathrm{N}$-acetylhistamine. The reaction mixture contained $40 \mu$ moles of Tris- $\mathrm{HCl}$ buffer $\left(\mathrm{pH} 8.0\right.$ ), $1 \mu$ mole of $\mathrm{MnCl}_{2}$, 6 emoles of $\mathrm{N}$-acetylhistamine and $0.3 \mathrm{ml}$ of enzyme solution in a final volume of $1.0 \mathrm{ml}$ which was incubated at $37^{\circ} \mathrm{C}$ for $2 \mathrm{hr}$. The reaction was stopped by lowering the $\mathrm{pH}$ to $2-3$ with $0.2 \mathrm{ml}$ of $0.1 \mathrm{M} \mathrm{H}_{3} \mathrm{PO}_{4}$. Histamine in the reaction mixture was determined by the author's' method reported previously (10) except for a slight modification to enable rapid determination. After centrifugation $(3,000 \mathrm{rpm}$ for $5 \mathrm{~min}$ ) of the reaction mixture, the supernatant was applied to a p-cellulose column $(1 \times 2.5 \mathrm{~cm})$ equilibrated with $0.06 \mathrm{M}$ phosphate buffer ( $\mathrm{pH}$ 6.2). After eluting out the unadsorbed materials including $\mathrm{N}$-acetylhistamine from the column with $8 \mathrm{ml}$ of $0.06 \mathrm{M}$ phosphate buffer $(\mathrm{pH} 6.2)$ and $5 \mathrm{ml}$ of $0.1 \mathrm{M}$ phosphate buffer ( $\mathrm{pH} 7.5$ ), histamine was eluted in the next $9 \mathrm{ml}$ of $0.1 \mathrm{M}$ phosphate buffer ( $\mathrm{pH} 7.5$ ). Histamine in the eluate was determined fluorometrically after the reaction with o-phthalaldehyde following the method of Shore et al. (11) with slight modifications (10). Non-enzymatic degradation of $\mathrm{N}$-acetylhistamine to histamine was not observed during the incubation of $\mathrm{N}$-acetylhistamine with boiled enzyme solution. In the experiments of incubation ( $2 \mathrm{hr}$ ) of histamine with enzyme solution, there was no loss of histamine from the action of histaminase or monoamine oxidase. Substrate-free reac-

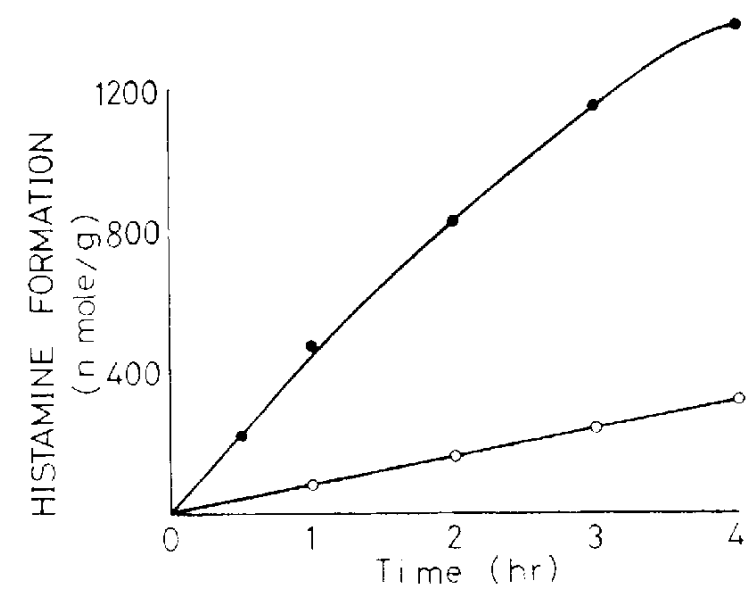

FiG. 1. Time courses of the deacetylating reactions of $\mathrm{N}$-acetylhistamine by the enzymes of the supernatants of the rat liver and brain

: liver, 0 : brain

The activity was determined in the presence of $1 \mathrm{mM} \mathrm{MnCl}$. 
tion mixture was always subjected to the same procedure as complete reaction mixture to obtain the blank value of the enzymatic reaction. The enzymatic activity was represented as nmole of histamine produced during 1 hr by the enzyme of the supernatant or sediment from $1 \mathrm{~g}$ of each tissue.

\section{RESULTS}

\section{Effects of time and $\mathrm{pH}$ on the deacetylation of $\mathrm{N}$-acetylhistamine}

Fig. 1 shows the time courses of the deacetylating reactions of $\mathrm{N}$-acetylhistamine by the enzymes of the rat liver and brain. The amounts of $0.5 \%$ and $0.1 \%$ of $\mathrm{N}$-acetylhista-
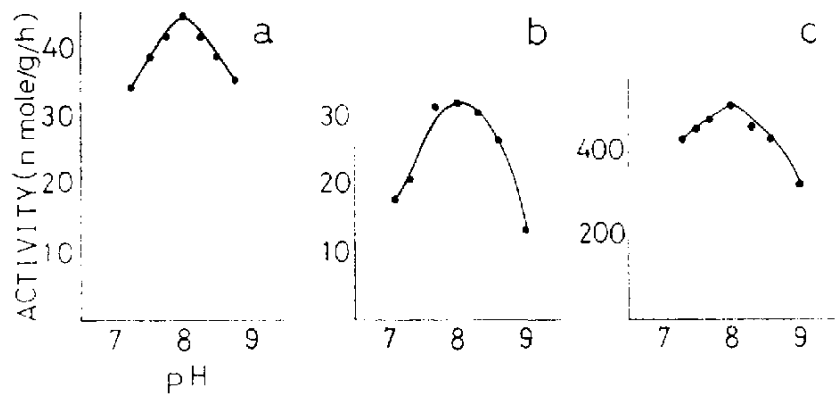

Fic. 2. pH-activity curves of $\mathrm{N}$-acetylhistamine deacetylating enzymes of the rat brain and liver

$a$ : supernatant of the brain, $b$ : sediments of the brain $c$ : supernatant of the liver

Tris-HCl buffer (pH 7-9) was used in the experiments. The activity was determined in the presence of $1 \mathrm{mM} \mathrm{MnCl}_{2}$.

TABLE 1. Distribution of the enzyme in the animal tissues.

The supernatant (Sup) and sediment (Sed) obtained from each tissue were subjected to the assay of enzymatic activity.

The activity was determined in the presence of $1 \mathrm{mM} \mathrm{MnCl}$. Each value is represented in $\mathrm{nmole} / \mathrm{g} / \mathrm{h}$.

\begin{tabular}{lcccccc}
\hline & \multicolumn{2}{c}{ Rat } & \multicolumn{2}{c}{ Mouse } & \multicolumn{2}{c}{ Guinea-pig } \\
& Sup & Sed & Sup & Sed & Sup & Sed \\
Liver & 360 & 55 & 248 & 26 & 125 & 8 \\
Spleen & 104 & 33 & 350 & 49 & 34 & 8 \\
Kidneys & 84 & 43 & 155 & 56 & 136 & 24 \\
Brain & 49 & 47 & 34 & 42 & 40 & 32 \\
Adrenals & 86 & 9 & -- & - & 44 & 5 \\
Testes & 52 & 22 & - & - & - & - \\
Appendix & 51 & 13 & -- & $-\ldots$ & - & - \\
Lungs & 28 & 2 & - & - & - & - \\
Stomach & 24 & 2 & - & - & - & - \\
S. intestine & 10 & 4 & -- & - & - & - \\
Heart & 9 & 1 & - & - & - & - \\
Muscles & 9 & 0 & - & - & - & - \\
Pancreas & 5 & - & - & - & - & - \\
Blood & 1.5 & 0.5 & - & - & - & - \\
\hline
\end{tabular}


mine in the reaction mixture were deacetylated during $2 \mathrm{hr}$ by the enzymes of the liver and brain of the rat, respectively. The activities of the enzymes of the rat liver and brain were measured in the $\mathrm{pH}$ range 7109 in Tris- $\mathrm{HCl}$ buffer. A pH optimum of 8.0 was observed in each enzyme (Fig. 2).

\section{Distribution of the enzyme in the animal tissues}

The enzymatic activity was observed in all tissues tested of the rat, mouse and guineapig (Table 1). The activity in the blood of rats were negligible. The deacetylating activity was also observed in the brain of the

bullfrog. Except for the brains, the major enzyme activities in these tissues were present in the supernatant fractions. In the brains from these animals, the activity was localized at the same level both in the supernatant and in the sediments. All activities in these tissues were enhanced in the presence of $1 \mathrm{mM} \mathrm{MnCl}$.

\section{Intracellular localization of activity}

The rat brain and liver were homogenized in ice-cold $0.25 \mathrm{M}$ sucrose and the homogenates were subjected to fractionation by centrifugation. The activity of
TABLE 2. Intracellular localization of activity. Rat brain and liver were homogenized in ice-cold $0.25 \mathrm{M}$ sucrose and the homogenates were subjected to fractionation by centrifugation. The activity was determined in the presence of 1 $\mathrm{mM} \mathrm{MnCl} \mathrm{I}_{2}$. Each value is represented with the ratio in $\%$ to the total activity of all fractions obtained from each tissue.

\begin{tabular}{lrc}
\hline \multicolumn{1}{c}{ Fraction } & $\begin{array}{c}\text { Brain } \\
(\%)\end{array}$ & $\begin{array}{c}\text { Liver } \\
(\%)\end{array}$ \\
Sediment $(1,000 \mathrm{~g})$ & 4 & 3 \\
Sediment $(10,000 \mathrm{~g})$ & 32 & 1 \\
Sediment $(100,000 \mathrm{~g})$ & 3 & 1 \\
Supernatant $(100,000 \mathrm{~g})$ & 61 & 95 \\
\hline
\end{tabular}

TABLE 3. Effects of metal ions on the deacetylating activities of the rat tissues.

\begin{tabular}{|c|c|c|c|c|c|c|c|c|c|c|c|c|}
\hline & \multicolumn{6}{|c|}{ Column-a } & \multicolumn{3}{|c|}{ Column-b } & \multicolumn{3}{|c|}{ Column-c } \\
\hline & B & $\mathrm{B}^{*}$ & L & $s$ & $\mathrm{~K}$ & A & B & $\mathrm{B}^{*}$ & $\mathbf{L}$ & B & $\mathrm{B}^{*}$ & $\mathrm{~L}$ \\
\hline None & 13 & 30 & 19 & 2 & 32 & 21 & 13 & 34 & 25 & $100 \#$ & $100 \#$ & 100 \\
\hline $\mathrm{CaCl}_{2}$ & 13 & 29 & 16 & 2 & 23 & 16 & 14 & 35 & 25 & 81 & 116 & 87 \\
\hline $\mathrm{MgCl}_{2}$ & 12 & 29 & 18 & 3 & 26 & 17 & 9 & 35 & 26 & 96 & 100 & 96 \\
\hline $\mathrm{CoCl}_{2}$ & 0 & 18 & 60 & 55 & 37 & 0 & 43 & 32 & 129 & 15 & 0 & 39 \\
\hline $\mathrm{CuSO}_{4}$ & 0 & 0 & 0 & 0 & 0 & 0 & 0 & 7 & 5 & 0 & 0 & 0 \\
\hline $\mathrm{ZnSO}_{4}$ & 0 & 0 & 0 & 0 & 0 & 0 & 0 & 1 & 0 & 0 & 0 & 0 \\
\hline $\mathrm{HgCl}_{2}$ & 0 & 0 & 0 & 0 & 0 & 0 & 0 & 1 & 0 & 0 & 0 & 0 \\
\hline $\mathrm{CdCl}_{2}$ & 0 & 0 & 0 & 0 & 0 & 0 & 0 & 2 & 0 & 0 & 0 & 0 \\
\hline РCMB & 0 & 0 & 0 & 0 & 0 & 0 & 0 & 12 & 2 & 0 & 0 & 0 \\
\hline $\mathrm{MnCl}_{2}$ & 100 & 100 & 100 & 100 & 100 & 100 & 100 & 100 & 100 & $90 \neq \geqslant$ & $93 \neq$ & $92 \%$ \\
\hline
\end{tabular}

Column-a : effects of $1 \mathrm{mM}$ metal ions

Column-b : effects of $0.1 \mathrm{mM}$ metal ions

Column-c : effects of $1 \mathrm{mM}$ metal ions in the presence of $1 \mathrm{mM} \mathrm{Mn} \mathrm{M}^{++}$.

Supernatant solution obtained from each tissue was used as enzyme solution.

$B$ : brain, $B^{*}$ : sediment of the homogenate of brain, L : liver,

$\mathrm{S}:$ spleen, $\mathrm{K}$ : kidneys, $\mathrm{A}:$ adrenals

\#: in the presence of $1 \mathrm{mM} \mathrm{Mn^{++ }}$ alone, $\#:$ in the presence of $2 \mathrm{mM} \mathrm{Mn}^{++}$

Each value is represented with the ratio in $\%$ in comparison with that in the presence of $1 \mathrm{mM} \mathrm{Mn}^{++}$. 
each fraction is shown in Table 2. In the brain, $61 \%$ and $31 \%$ of the activity of the tissue was observed in $100,000 \mathrm{~g}$ supernatant and $10,000 \mathrm{~g}$ sediment, respectively. On the other hand, in the liver the activity was observed only in the 100,000 g supernatant.

\section{Effects of metal ions on the activity}

The effects of metal salts on the activities of the deacetylating enzymes in the tissues of the rat are shown in Table 3.

Column-a shows the effects of $1 \mathrm{mM}$ metal salts. Similar results were obtained from the experiments using $\mathrm{H}_{3} \mathrm{BO}_{3}-\mathrm{Na}_{2} \mathrm{~B}_{4} \mathrm{O}_{7}$ buffer and $\mathrm{H}_{3} \mathrm{BO}_{3}-\mathrm{Na}_{2} \mathrm{CO}_{3}$ buffer. With $0.1 \mathrm{mM}$ and $1 \mathrm{mM}, \mathrm{NaCl}, \mathrm{KCl}, \mathrm{LiCl}$ and $\left(\mathrm{NH}_{4}\right)_{2} \mathrm{SO}_{4}$ had no effect on the activity of the enzyme prepared from the rat liver homogenized in $0.25 \mathrm{M}$ sucrose. These results suggest that anions of these salts have no effect on the activity. The deacetylating activitics of all these tissues were markedly enhanced by the addition of $\mathrm{Mn}^{++}$, but not by $\mathrm{Ca}^{++}$and $\mathrm{Mg}^{++}$. $\mathrm{Cu}^{++}, \mathrm{Zn}^{++}, \mathrm{Hg}^{++}$and $\mathrm{Cd}^{++}$inhibited the activity completely. p-Chloromercuric benzoate (PCMB) showed complete inhibition. The variant effects of $\mathrm{CO}^{++}$were observed among the tissues. With $1 \mathrm{mM}$ $\mathrm{Co}^{++}$, an inhibitory effect on the brain and adrenals and an activating effect in the liver and spleen were observed. These effects of $1 \mathrm{mM}$ metal ions were also similar in the enzymes of the tissues of mice and guinea-pigs. In the following experiments, the supernatant and sediment of the rat brain and the supernatant of the rat liver were used as enzymes for a comparison of the properties of each enzyme.

Column-b shows the effects of $0.1 \mathrm{mM}$ metal ions. An activating effect on the deacetylating enzymes of the supernatants of the brain and liver occurred with 0.1 $\mathrm{mM} \mathrm{Co}{ }^{++}$. In the supernatant of the liver, the activating effect of $\mathrm{Co}^{++}$was higher than that of $\mathrm{Mn}^{++}$.

Column-c shows the effects of $1 \mathrm{mM}$
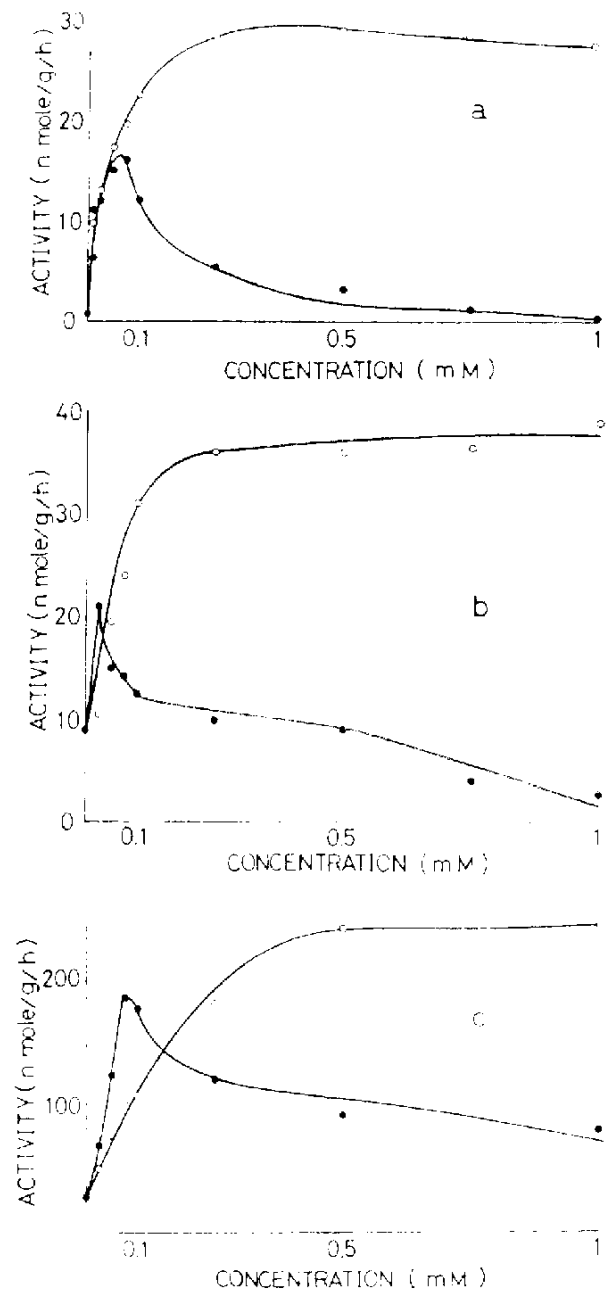

FIG. 3. Effects of $\mathrm{Co}^{++}$and $\mathrm{Mn}^{++}$on the activities of the enzymes of the brain and liver of the rat

O : $\mathrm{Co}^{++}, \mathrm{O}: \mathrm{Mn}^{++}$, a : supernatant of the brain, $b$ : sediment of the brain, $c$ : supernatant of the liver.

The reaction mixtures containing various amounts of $\mathrm{CoCl}_{2} \mathrm{MnCl}_{2}$ and other reagents were incubated. 
metal ions in the presence of $1 \mathrm{mM} \mathrm{Mn}{ }^{++}$. $\mathrm{Ca}^{++}$and $\mathrm{Mg}^{++}$were ineffective and $\mathrm{Cu}^{++}$, $\mathrm{Zn}^{++}, \mathrm{Hg}^{++}$and $\mathrm{Cd}^{++}$were inhibitory as in the case of each metal ion alone. The effect of $\mathrm{Co}^{++}$, in this case, is only inhibitory.

These effects of $\mathrm{Mn}^{++}$and $\mathrm{CO}^{++}$on the deacetylating activities of the enzymes of the brain and liver of the rat are illustrated in Fig. 3. The inhibitory and activating effects of $\mathrm{Co}^{++}$described above are shown clearly in the figures. $\mathrm{Co}^{++}$ enhanced the activity at a low concentration while it was inhibitory at a high concentration.

From these results it is concluded, that regarding the effects of metal ions, there is no substantial difference among the enzymes in different tissues.

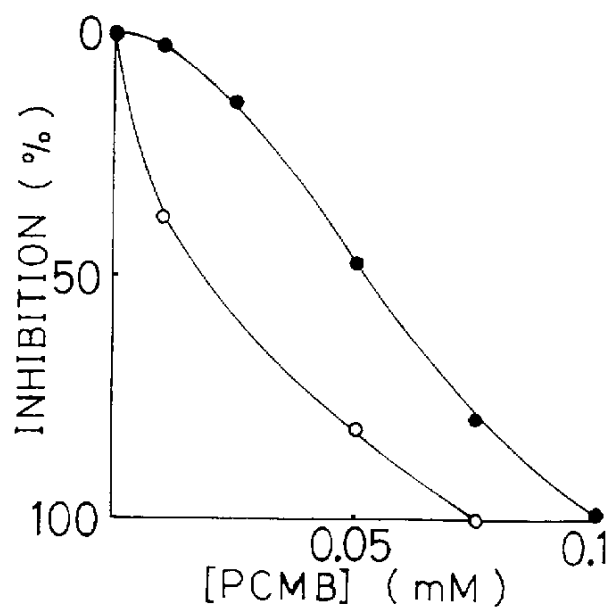

FIG. 4. Inhibition by p-chioromercuric benzoate of the deacetylation of $\mathrm{N}$-acetylhistamine

- : supernatant of the rat liver, $O$ : supernatant of the rat brain.

The activity was determined in the presence of various amounts of PCMB under the conditions described in the text.

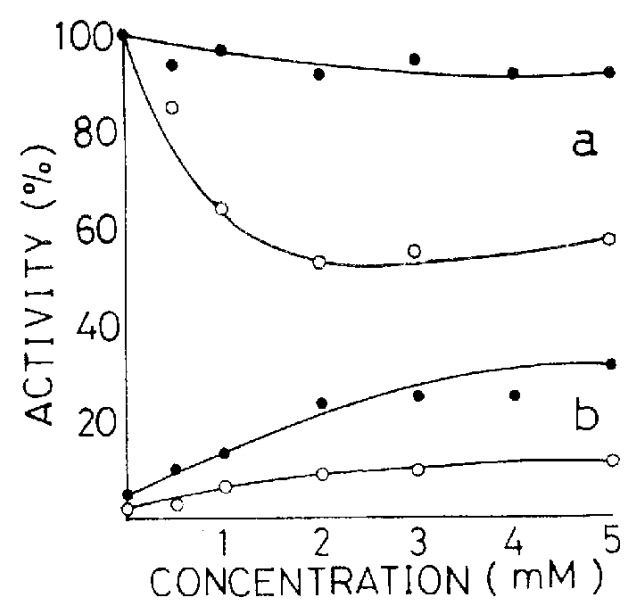

Fig. 5. Effects of glutathione-SH and cysteine on the activity of the rat liver enzyme a : Effects of each reagent on the activity without PCMB treatment

- : glutathione-SH, $\mathrm{O}$ : cysteine

Reactions were carried out in the presence of each reagent under the conditions described in the text.

b : Effect of each reagent on PCMB-inhibited activity

- : glutathione-SH, $O$ : cysteine

Reaction mixture containing $0.2 \mathrm{ml}$ of $0.2 \mathrm{M}$ Tris- $\mathrm{HCl}$ buffer $(\mathrm{pH} 8.0$ ), 0.1 $\mathrm{ml}$ of $10 \mathrm{mM} \mathrm{MnCl}{ }_{2}, 0.1 \mathrm{ml}$ of $1 \mathrm{mM} \mathrm{PCMB}$ and $0.3 \mathrm{ml}$ of enzyme solution was pre-incubated for $15 \mathrm{~min}$ at $37^{\circ} \mathrm{C}$, after which glutathione-SH or cysteine $(0.1 \mathrm{~m})$ was added. After the addition of $0.2 \mathrm{ml}$ of $30 \mathrm{mM} \mathrm{N}$-acetylhistamine, the reaction mixture was incubated for $2 \mathrm{hr}$ at $37^{\circ} \mathrm{C}$. 
The presence of two different enzymes, one dependent on $\mathrm{Co}^{++}$and the other on $\mathrm{Mn}^{++}$, seems less feasible, since no additive effect by $\mathrm{CO}^{++}$and $\mathrm{Mn}^{++}$on the rat liver enzyme was observed in the presence of either $0.1 \mathrm{mM} \mathrm{Co}^{++}$or $1 \mathrm{mM} \mathrm{Mn}^{++}$.

Effects of PCMB and glutathione-SH on the activity

PCMB inhibited the activities of the enzymes in all tissues tested (Table 3, Fig. 4). On the other hand, Fig. 5 shows the effects of glutathione-SH and cysteine on the activity of the rat liver enzyme. Glutathione-SH had no significant effect on the activity at a concentration $0-5 \mathrm{mM}$, and cysteine had an inhibitory effect (Fig. 5-a). The PCMB-inhibited activity was partially restored by glutathione-SH $(30 \%)$ and cysteine $(10 \%)$ (Fig. 5-b). The restoration of PCMB-inhibited activity by glutathione-SH was observed also in the enzymes of the supernatant and sediment of the rat brain. These results suggest that the deacetylating enzyme may involve a thiol group in the active site.

Effect of sulstrate concentration of the rate of deacetylation

The rates of deacetylation of various amounts of $\mathrm{N}$-acetyl-histamine with the enzymes of the rat liver and brain followed the Michaelis-Menten kinetics (Fig. 6). The $\mathrm{Km}$ values of the enzymes of the liver, the supernatant and the sediment of the brain were $1.1 \mathrm{mM}$, $6.7 \mathrm{mM}$ and $4.8 \mathrm{mM}$, respectively.

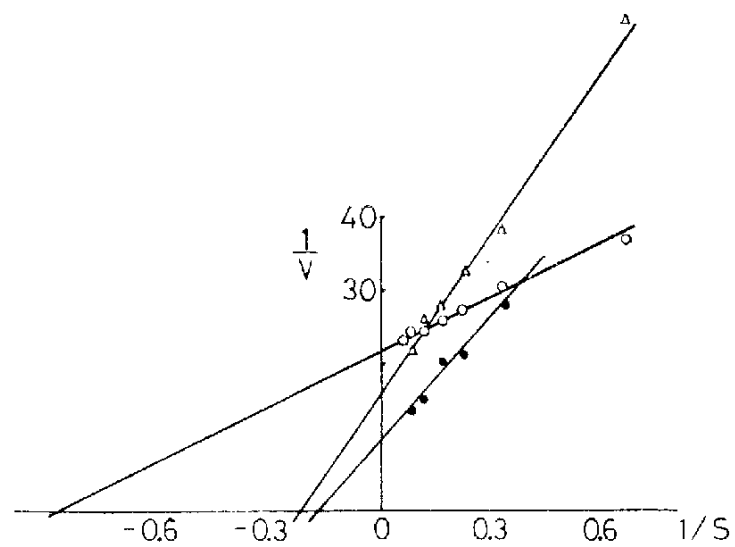

FIc. 6. Effect of substrate concentration on the rate of deacetylation

$0:$ enzyme of the rat liver $\left(\times 10^{4}\right)$

- : enzyme of the supernatant of the rat brain $\left(\times 10^{3}\right)$

$\triangle:$ enzyme of the sediment of the rat brain $\left(\times 10^{3}\right)$

$\mathrm{V}:$ nmole/g/h, $\mathbf{S}: \mathbf{m M}$

The reaction mixtures containing various amounts of $\mathrm{N}$-acetylhistamine and other reagents were incubated for $2 \mathrm{hr}$ at $37^{\circ} \mathrm{C}$.

\section{DISCUSSION}

Enzymatic acetylation of biogenic amines has been well documented $(1,2,3,5,6,7$, 36, 37). In the present study, enzymatic deacetylation was demonstrated. The enzyme catalyzing the deacetylation of $\mathrm{N}$-acetylhistamine was found to be distributed widely among animal tissues. The activity was markedly enhanced by the addition of $\mathrm{Mn}^{++} . \mathrm{Na}^{+}$, 
$\mathrm{K}^{+}, \mathrm{Li}^{+}, \mathrm{Ca}^{++}$and $\mathrm{Mg}^{++}$had no effect. $\mathrm{Co}^{++}$enhanced the activity at a low concentration and inhibiled it at a high concentration. $\mathrm{Cu}^{++}, \mathrm{Zn}^{++}, \mathrm{Hg}^{++}, \mathrm{Cd}^{++}$and PCMB inhibited the activity. The PCMB-inhibited activity was partially restored by the addition of glutathione-SH or cysteine. Thus it appears that a thiol group is involved in the active site of the enzyme. The major activity was localized in the cellular soluble fraction of tissues. These enzymatic properties were common among the enzymes of different tissues. Whether or not other acetylated biogenic amines are substrates of the present enzyme remains to be elucidated. With respect to the brain, significant levels of enzymatic activity were observed also in the fraction of $10,000 \mathrm{~g}$ sediment (mitochondrial fraction).

When the properties of the enzyme catalyzing the deacetylation of $\mathrm{N}$-acetylhistamine are compared with the reported properties of other enzymes acting on peptide and the same $\mathrm{C}-\mathrm{N}$ bonds other than peptide bonds, same of the same characteristics are evident. For example, proline iminopeptidase (EC 3.4.1.4) (12, 13), glycyl-glycine dipeptidase (EC 3.4.3.1) $(14,15,16)$, cysteinyl-glycine dipeptidase $(\mathrm{EC} 3.4 .3 .5)(17,18)$, prolinase (EC 3.4.3.7) $(19,20,21)$, aminoacylase I (EC 3.5.1.14) (22, 23), arginase (EC 3.5.3.1) (24, 25) and some of arylamidases (26) are activated by $\mathrm{Mn}^{++}$or $\mathrm{Co}^{++}$or both. Although enzymes such as leucine aminopeptidase $(E C$ 3.4.1.1) (27, 28), glycyl-leucine dipeptidase (EC 3.4.3.2) (29), carnosinase (EC 3.4.3.3) (30) and anserinase (EC 3.4.3.4) (31, 32) are activated also by $\mathrm{Mn}^{++}$or $\mathrm{Co}^{++}$, they have other properties apparently different from those of $\mathrm{N}$-acetylhistamine-deacetylating enzyme. Recently, Franklin et al. $(33,34)$ reported an enzyme activated by $\mathrm{Mn}^{++}$and which catalyzed the deacetylation of p-acetamidobenzoic acid in rat tissues. The distribution of this particular enzyme is different from that of $\mathrm{N}$-acetylhistamine-deacetylating enzyme. Baslow and Lenney (35) reported no deacetylating activity of $\mathrm{N}$-acetylhistamine by $\alpha$-N-acetyl-L-histidine aminohydrolase. There has been no documentation of the deacetylation of $\mathrm{N}$-acetyl biogenic amines or $\mathrm{N}$-acetylhistamine by these enzymes.

As $\mathrm{N}$-acetylated biogenic amines in general have litıle pharmacological action, $\mathrm{N}$ acetylation may represent in mammals a process of inactivation in addition to such reactions as methylation and oxidative deamination. It may be that this pathway opens up particularly in the presence of an excess of amines, or when other routes of degradation are blocked, e.g. by monoamine oxidase inhibitors $(6,36)$. In contrast with these views, Sekeris and Karlson (37) discussed the possible regulatory role of $\mathrm{N}$-acetyldopamine on the biosynthesis of catecholamines in the adrenals by a feedback inhibition, N-acetyldopamine being a potent inhibitor of dopa decarboxylase. If other $\mathrm{N}$-acetyl biogenic amines have the same actions as $\mathrm{N}$-acetyldopamine, it is also possible that the deacetylating enzyme may play a role in the regulation of the levels of $\mathrm{N}$-acetyl biogenic amines. In any case, it should be clarified whether or not the enzyme catalyzing the deacetylation of $\mathrm{N}$ acetylhistamine has other specific functions.

Acknowledgement: We thank Sankyo Co., Ltd. for the gencrous gift of N-acetylhistamine. 


\section{REFERENCFS}

1) Millican, R.C.: Arch. Biochem. Biophys., 42, 399 (1953)

2) TABOR, H.: Pharmacol. Rev., 6, 329 (1954)

3) Schayer, R.W.: Physiol. Rev., 39, 121 (1959)

4) Werle, E. ANd PALM, D.: Biochem. Zeitschrift, 323, 255 (1952)

5) Tabor, H., Mferler, A.H. and Stadman, E.R.: J. biol. Chem., 204, 127 (1953)

6) Weissbach, H., Redfield, B.G. A.vd Axelrod, J.: Biochem. biophys. Acta., 54, 190 (1961)

7) Sekeris, C.E. And Herrlici, P.: Hoppe-Seyler's Z. Physiol. Chem., 336, 130 (1964)

8) S.IAASTAD, O.: Nature, 216, 1111 (1967)

9) Merwe, P.: Hoppe-Seyler's Z. Physiol. Chom., 177, 308 (1928)

10) Endo, Y. avd Ogura, Y.: Europ. J. Pharmacol., 21, 293 (1973)

11) Shore, P.A., Burkhalter, A. A.vd Cohn, V.H.Jr.: J. Pharmacol. exp. Ther., 127, 182 (1959)

12) Sarid, S., BergliR, A. and Katchialski, E.: J. biol. Chem., 234, 1740 (1959)

13) Sarid, S., Blrgilir, A. and Katchalskt, E.: J, biol. Chcm., 237, 2207 (1962)

14) Sмith, E.L.: J. biol. Chem., 173, 571 (1948)

15) Sмimи, F.L.: J. hiol. Chem., 176, 21 (1948)

16) BERGer, J. AND JoHNSON, M.J.: J. biol. Chem., 130, 641 (1939)

17) OISON, C.K. AND BinKLEY, F.: J. biol. Chem., 186, 731 (1950)

18) BiNKLEY, F.: Nature $, 167,888$ (1951)

19) Smith, E.L. and Berguan, M.: J. biol. Chem., 153, 627 (1944)

20) Adams, E. AND SMiTH, E.L.: J. biol. Chem., 198, 671 (1952)

21) Davis, N.C. ANd Smitif, E.L.: J. biol. Chem., 224, 261 (1957)

22) Birnbaum, S.M., Levintow, L., Kingsley, R.B. and Greenstein, J.P.: J. biol. Chem., 194, 445 (1952)

23) Rao, K.R., Birnbaum, S.M., Kingslly, R.B. and Grefnstein, J.P.: J. biol. Chem., 198, 507 (1952)

24) Archibal.D, R.M.: J. biol. Chem., 157, 507 (1945)

25) BACH, S.J. AхD KillelP, L.D.: Biochem. biophys. Acia., 47, 336 (1961)

26) Brecher, A.S. And Sliszkiw, J.B.: Riochem. J., 112, 335 (1969)

27) Sprckman, D.H., Smith, E.L. and Brown, D.M.: J. biol. Chem., 212, 255 (1955)

28) Smith, E.L. ANd Spackman, D.H.: J. biol. Chem., 212, 271 (1955)

29) SMIIH, E.L.: J. hiol. Chem., 176, 9 (1948)

30) Hanson, H.T. and S.MrTh, E.L.: J. biol. Chem., 179, 789 (1949)

31) JONES, N.R.: Biochem., J. 60, 81 (1955)

32) Jonts, N.R.: Boichem. J., 64, 20p (1956)

33) Franklin, M.R., Bridge,s, J.W. nND Wilitams, R.T.: Biochem. J., 114, 6p (1969)

34) Fravklin, M.R., Bridges, J.W. and Williams, R.T.: Xenobiotica, 1, 121 (1971)

35) Bastow, M.H. ANd Lenney, J.F.: Can. J. Biochem., 45, 337 (1967)

36) Michflson, M.J.: Comparative Pharmacology, vol. 1, p. 391 Pergamon Press, New York (1973)

37) Sexeris, C.E. And Karlson, P.: Pharmacol. Rev., 18, 92 (1966) 